\title{
Investigation of chromosomal alterations in patients with Alzheimer's disease in the state of Amazonas, Brazil
}

\author{
Investigação de alterações cromossômicas em pacientes com doença de Alzheimer no \\ estado do Amazonas, Brasil \\ Kledson Moraes NUNES', Denise Corrêa BENZAQUEM', Natalia Dayane Moura CARVALHO', Talísia \\ Nascimento VIANEZ², Ernanda Raquel de Queirós Gonçalves de Sousa e FERNANDES ${ }^{3}$, Cleiton FANTIN ${ }^{1}$
}

\begin{abstract}
Alzheimer's disease (AD) has as its main characteristic the deterioration of cerebral functions. Its etiology is still complex and undefined despite the progress made in understanding its neurological, infectious, biochemical, genetic and cytogenetic mechanisms. Considering this, the aim of this study was to investigate the presence of chromosomal alterations in the peripheral blood lymphocytes, and to verify if there was a high frequency of these alterations in patients diagnosed with AD at the University Hospital Getúlio Vargas Outpatient Clinic Araújo Lima in Manaus, Amazonas, Brazil. Among the nine patients in the AD group, only one patient did not have metaphases with chromosomal alterations $(2 n=46, X X)$, while eight patients with AD showed numerical chromosomal alterations, classified as $X$ chromosome aneuploidy $(2 n=45, X)$ and double aneuploidy $(2 n=44, X,-X,-10 ; 2 n=44, X,-X,-13$ and $2 n=44, X,-X,-21)$. In the control group, no chromosomal changes were found in the karyotypes of these individuals. Therefore, the karyotypes of patients with AD undergo chromosomal alterations at different levels. These findings are being described for the first time in the population of Amazonas, and they highlight the importance of the inclusion of cytogenetic investigations in the routine management of patients with AD.
\end{abstract}

Keywords: Alzheimer's disease; genetics; chromosome detetion.

\section{RESUMO}

Doença de Alzheimer (DA) tem como principal característica a deterioração das funções cerebrais. Quanto a sua etiologia ainda é complexa e indefinida, apesar do progresso alcançado na compreensão de seus mecanismos neurológicos, infecciosos, bioquímicos, genéticos e citogenéticos. Considerando isto, nós investigamos a presença de alterações cromossômicas nos linfócitos de sangue periférico e verificamos se há uma alta frequência dessas alterações em pacientes já diagnosticados com doença de Alzheimer no Hospital Universitário Getulio Vargas / Ambulatório Araújo Lima, Manaus / Amazonas / Brasil. Assim, dos 09 pacientes do grupo DA, somente 01 paciente não apresentou metáfases com alterações cromossômicas $(2 n=46, X X)$ enquanto que 08 pacientes com DA apresentaram alterações cromossômicas numéricas, sendo classificadas como aneuploidia do cromossomo $X(2 n=45, X)$ e aneuploidia dupla $(2 n=44, X,-X,-10 ; 2 n=44, X,-X,-13$ e $2 n$ $=44, X,-X,-21)$. No grupo controle, não foram encontradas alterações cromossômicas nos cariótipos desses indivíduos. Estes achados para a população do Amazonas/ Brasil estão sendo descritos pela primeira vez. Os cariótipos de pacientes com DA sofrem alterações cromossômicas em diferentes níveis e demonstraram a importância das investigações citogenéticas no manejo rotineiro de pacientes com DA.

Palavras-chave: Doença de Alzheimer; genética; deleção cromossômica.

One of the most common types of dementia among older adults is Alzheimer's disease $(\mathrm{AD})$. The main characteristic of this disease is the deterioration of cerebral functions, with the occurrence of memory loss, which can irreversibly progress, affecting the motor functions, even leading to the death of the individual ${ }^{1}$. Neuropathological alterations include mainly

\footnotetext{
'Universidade do Estado do Amazonas, Escola Superior de Ciências da Saúde, Laboratório de Citogenética, Manaus AM, Brasil;

¿2Universidade Federal do Amazonas, Hospital Universitário Getúlio Vargas, Departamento de Neurologia, Manaus AM, Brasil;

${ }^{3}$ Universidade Federal do Amazonas, Hospital Universitário Getúlio Vargas, Laboratório de Análises Clínicas, Manaus AM, Brasil.

Kledson Moraes Nunes (iD) http://orcid.org/0000-0002-4308-0982; Denise Corrêa Benzaquem (iD http://orcid.org/0000-0002-5394-7455; Natalia Dayane Moura Carvalho (iD http://orcid.org/0000-0002-8513-0749; Talísia Nascimento Vianez (iD http://orcid.org/0000-0002-7275-7542; Ernanda Raquel de Queirós Gonçalves de Sousa e Fernandes (iD) https://orcid.org/0000-0002-8472-3171; Cleiton Fantin (iD) http://orcid.org/0000-0002-4801-698X Correspondence: Cleiton Fantin; Universidade do Estado do Amazonas Escola Superior de Ciencias da Saude; Av. Carvalho Leal, 1777; 69065-001 Manaus AM, Brasil; E-mail: cleitonfantin@hotmail.com

Conflict of interest: There is no conflict of interest to declare.

Received 03 May 2019; Received in final form 12 July 2019; Accepted 05 August 2019.
} 
the formation of neurofibrillary tangles and alterations in the amyloid metabolism, causing synaptic loss and neuronal death $^{1,2}$. The etiology of $\mathrm{AD}$ is still considered complex and undefined, despite the progress made in the understanding of its biochemical and genetic mechanisms ${ }^{3,4}$. Genetic studies have highlighted four genes responsible for $\mathrm{AD}$ : amyloid precursor protein, presenilin-1, presenilin-2 and apolipoprotein $E^{5}$.

Cytogenetic analyses in patients diagnosed with $\mathrm{AD}$ have demonstrated a significant increase in numerical chromosomal alterations in different cell types of these patients ${ }^{6}$. Subsequent studies have also shown numerical chromosomal alterations related to the $\mathrm{X}$ chromosome, indicating a characteristic to be evaluated in these patients ${ }^{7,89}$. To date, there is no cytogenetic information available about patients with $\mathrm{AD}$ in the state of Amazonas, Brazil. The genes associated with $\mathrm{AD}$ have already been chromosomally mapped. The apolipoprotein E gene is located on chromosome 19q13.32, the presenilin-1 gene on chromosome 14q24.2, the presenilin-2 gene on chromosome 1q42.13 and the amyloid precursor protein gene is located on chromosome $21 \mathrm{q} 21.3^{10,11,12}$.

Accordingly, the aim of this study was to perform cytogenetic analyses in nine patients diagnosed with $\mathrm{AD}$, as well as in nine healthy individuals, attending the University Hospital Getúlio Vargas Outpatient Clinic Araújo Lima in Manaus, Amazonas, Brazil. Conventional cytogenetic markers (conventional staining and G-banding) were used to investigate the presence of chromosomal alterations in peripheral blood lymphocytes and to verify whether there was a high frequency of these alterations in $\mathrm{AD}$ patients of Manaus.

\section{METHODS}

The study was approved by the Research Ethics Committee of the Amazonas State University, under the authorization number 2.456.885 (CAAE: 66630616.6.0000.5016). The individuals studied were referred by doctor Talísia Vianez from the Department of Neurology at the University Hospital Getúlio Vargas Outpatient Clinic Araújo Lima. The cohort included nine individuals (one man and eight women), aged between 62 and 85 years, who had previously been diagnosed with $\mathrm{AD}$, for at least three years; and nine healthy individuals (control group, one man and eight women) of the same age group. The purpose of the research was explained to all patients, and all signed the Informed Consent Term, as required by the National Health Council. All the patients were submitted to the Mini-Mental State Examination (MMSE) to evaluate their cognitive functions ${ }^{13}$. The MMSE scores were used to classify the cognitive impairment of the patients into three levels: $24-30$ = no cognitive impairment; 18-23 = mild cognitive impairment; and $0-17=$ severe cognitive impairment ${ }^{14}$.

Cytogenetic analyses were performed at the Laboratory of Cytogenetics of the Amazonas State University. Metaphase mitotic chromosomes were obtained from lymphocyte culture ${ }^{15}$. G-banding was obtained using trypsin solution ${ }^{16}$. Metaphases were karyotyped using the GeneALL program, and the chromosomal alterations were classified according to the International System for Human Cytogenetic Nomenclature.

\section{RESULTS}

The characteristics of the $\mathrm{AD}$ patients (age, MMSE test scores and diagnosis year) and the chromosomal alterations found in these patients are shown in the Table. Based on MMSE scores, eight patients were in the category of severe cognitive impairment (0-17 points), of whom two did not score any points; and one patient was in the category of mild cognitive impairment (18-21 points).

A total of 100 metaphases were analyzed from each $\mathrm{AD}$ patient and individual in the control group. Among the nine patients of the $\mathrm{AD}$ group, only one (B-09) did not have metaphases with chromosomal alterations $(2 n=46, X X$; Figure 1A). The other eight showed metaphases with numerical chromosomal alterations related to the loss of one of the X chromosomes $(2 n=45, X)$, as well as with the concomitant loss of a $\mathrm{X}$ chromosome and an autosomal chromosome $(2 \mathrm{n}=4, \mathrm{X},-\mathrm{X},-10 ; 2 \mathrm{n}=44, \mathrm{X},-\mathrm{X},-13$ and $2 \mathrm{n}=44, \mathrm{X},-\mathrm{X},-21)$ (Figure B, C). Chromosomal aneuploidies identified in the $\mathrm{AD}$ group were classified as X chromosome aneuploidy and double aneuploidy (loss of one X chromosome and autosomes) (Table). In the control group, all individuals underwent the same process of chromosomal analysis and no chromosomal alterations were found in their karyotypes.

\section{DISCUSSION}

Alzheimer's disease is a chronic neurodegenerative disorder, which compromises cognitive functions and the individual's behavior, social and professional life ${ }^{17}$. Chromosome studies in $\mathrm{AD}$ patients have shown the presence of chromosomal alterations, as well as a high frequency of these changes in the karyotypes of patients with $\mathrm{AD}$, suggesting that these alterations may be associated with the disease ${ }^{18,19,20}$.

Chromosomal alterations of aneuploid type in $\mathrm{AD}$ patients have been reported in the different cell types, suggesting that there is a systemic chromosome instability in $\mathrm{AD}$. In the neuronal cells in $\mathrm{AD}$ patients, aneuploidy potentially contributes to functional decline and predisposition to the disease, and a two-fold increase in $\mathrm{X}$ chromosome aneuploidy rates has been shown in neural cells of the hippocampus and cerebrum, which are dramatically affected by neurodegeneration'. Non-neural cells (peripheral blood lymphocyte cells, buccal cells and fibroblast tissue) were isolated from $\mathrm{AD}$ patients and showed increased aneuploidy X chromosome and autosomal chromosomes ${ }^{21}$. Chromosome instability 


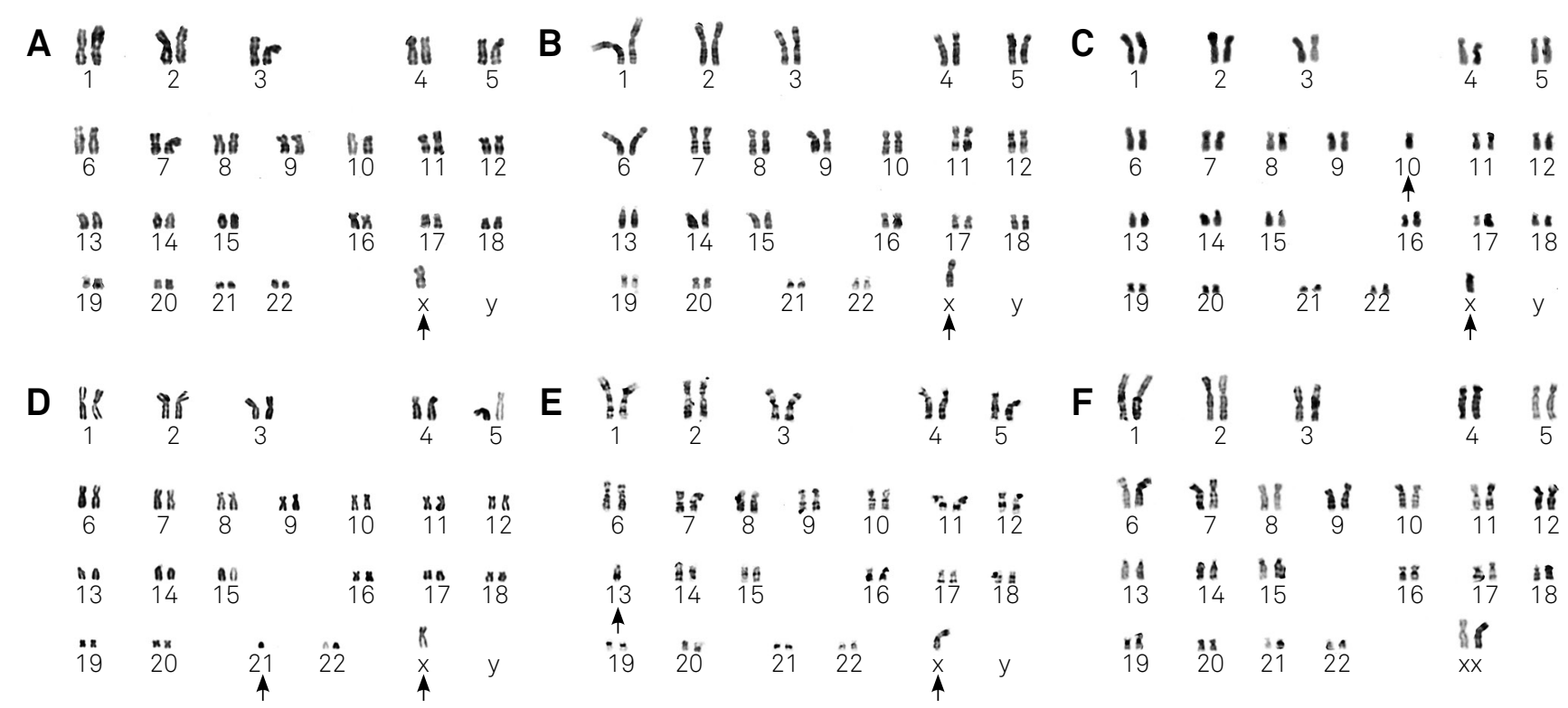

Figure. Karyotypes of patients diagnosed with Alzheimer's disease: (A and B) loss of one homologue of the sex chromosome X; (C) loss of one homologue of the chromosomal pair 10 and the sex chromosome X; (D) loss of one homologue of the chromosomal pair 21 and the sex chromosome X; (E) loss of one homologue of the chromosomal pair 13 and the sex chromosome X; (F) Patient without chromosomal alteration.

Table. Characteristics of the patients in the Alzheimer's disease group. Age, the scores of the MMSE test, year of diagnosis of the disease, chromosomal alterations of patients with Alzheimer's disease.

\begin{tabular}{|c|c|c|c|c|c|c|}
\hline \multirow{2}{*}{ Patient } & \multirow{2}{*}{ MMSE score } & \multirow{2}{*}{ Age } & \multirow{2}{*}{ Year of diagnosis } & \multicolumn{2}{|c|}{ Aneuploidy } & \multirow[b]{2}{*}{$\mathrm{n}$} \\
\hline & & & & Monosomy of X chromosome & Double monosomy & \\
\hline B-01 & 6 & 71 & 2012 & $45, x$ & - & 5 \\
\hline B-02 & 0 & 79 & 2010 & $45, Y$ & - & 4 \\
\hline B-03 & 0 & 79 & - & $45, x$ & - & 3 \\
\hline \multirow{2}{*}{ B-04 } & \multirow{2}{*}{8} & \multirow{2}{*}{86} & \multirow{2}{*}{2011} & $45, x$ & - & 3 \\
\hline & & & & - & $44, X,-X,-10$ & 1 \\
\hline B-05 & 16 & 67 & 2013 & $45, x$ & - & 5 \\
\hline B-06 & 5 & 79 & 2010 & - & $44, X,-X,-21$ & 1 \\
\hline \multirow{2}{*}{ B-07 } & \multirow{2}{*}{21} & \multirow{2}{*}{62} & \multirow{2}{*}{-} & $45, x$ & - & 1 \\
\hline & & & & - & $44, X,-X,-13$ & 1 \\
\hline B-08 & 12 & 74 & 2011 & $45, x$ & - & 1 \\
\hline B-09 & 14 & 69 & - & - & - & - \\
\hline
\end{tabular}

results in loss or gain of chromosome in different cells and tissue as well as harmful effects on organism physiology, and is considered a risk factor for $\mathrm{AD}$ neuropathogenesis ${ }^{21,22}$.

Cytogenetic analyses performed in the present study with patients diagnosed with $\mathrm{AD}$ revealed that only one patient did not show any numerical and/or structural chromosomal alterations $(2 n=46, X X)$. On the other hand, the presence of aneuploidies was observed in the karyotypes of eight patients diagnosed with $\mathrm{AD}(2 \mathrm{n}=45, \mathrm{X})$, which corroborates the literature data available for other localities ${ }^{7,8.9}$. When comparing these results with the healthy elderly, no type of chromosomal alteration was observed, presenting with only normal metaphase cells (46,XX and 46,XY). This demonstrates that these alterations are associated with $\mathrm{AD}$, which seems to favor the loss of one of the $\mathrm{X}$ chromosomes and one of the autosomal chromosomes (chromosomes 10, 13 and 21). This is the first record of chromosomal alterations in $\mathrm{AD}$ patients of the state of Amazonas.

The X chromosome contains some genes that are associated with the nervous system. Chromosomal syndromes resulting from the loss of $\mathrm{X}$ can influence the cognitive capacity of the individual, and intellectual deficiency is the main characteristic of these syndromes ${ }^{23,24}$. Karyotype analysis performed in patients with non-Down syndrome intellectual disability, attending the APAE-Manaus, identified one patient with mosaic Turner syndrome (45,X/46,XX) detected by classical cytogenetics, demonstrating a correlation between the loss of X chromosome and intellectual deficiency ${ }^{25}$. Although a relationship between X chromosome loss and cognitive/intellectual impairment in certain 
diseases is evident, in the present study, no direct evidence of a correlation between the $\mathrm{X}$ chromosome loss and the degree of cognitive impairment (MMSE test) was found in $\mathrm{AD}$ patients. There was also no association between chromosomal loss and age or time to diagnosis, which emphasizes the need for complementary studies.

Several authors have suggested that the relatively high frequency of chromosomal alterations was not necessarily related to $\mathrm{AD}$ itself, but rather to aging ${ }^{7,26}$. Alzheimer's disease is a systematic disease that accelerates aging. It has been proposed that the $\mathrm{X}$ chromosome may underlie the instability of the $\mathrm{AD}$ cell genome, leading to a significant level of aneuploidy and a high percentage of premature centromere divi$\operatorname{sion}^{27,28}$. Premature centromere division is one of the cellular events that causes loss of the control of the segregation of the centromeres, contributing to the emergence of chromosomal alterations $^{28,29}$. Furthermore, the concomitant loss of one of the sex chromosomes (X chromosome) and one of the autosomal chromosomes (one of the homologues of the chromosome pairs 10, 13 and 21) has been described in $\mathrm{AD}$ patients for the first time. Double aneuploidies (gain or loss of two or more chromosomes) have been rarely reported in the literature. The mechanism underlying the origin of double aneuploidy is unclear. It has been hypothesized that double aneuploidy results either from two nondisjunctional events in gametogenesis or from a single nondisjunctional event in a trisomic zygote ${ }^{30,31}$. Regarding the autosomal chromosomes, one of the main genes involved in $\mathrm{AD}$, the amyloid precursor protein gene, is located on chromosome $21^{32}$. Amyloid precursor protein is directly linked to $\mathrm{AD}$ pathogenesis, and it was one of the first genes to be associated with chromosomal alterations. Down syndrome patients (chromosome 21 trisomy), who usually manifest this neuropathology around the age of 40 years, have a greater expression of the amyloid precursor protein gene $\mathrm{e}^{33,34,35}$. It is worth mentioning that aneuploidy of other types of autosomes $(1,7,11,14,17$ and 18) has also been reported in $\mathrm{AD}$ patients, indicating a significant increase in aneuploidies of autosomal chromosomes ${ }^{9,17}$.

In conclusion, the results of the present study, together with literature data, indicate that the karyotypes of patients diagnosed with $\mathrm{AD}$ go through different levels of chromosomal alterations, reinforcing the importance of the use of cytogenetic analyses (cytogenetic markers) in medical trials. Additional studies are needed to understand the implications of the loss of $\mathrm{X}$ chromosomes involved in patients with Alzheimer’s disease in Manaus, Amazonas, Brazil.

\section{Acknowledgments}

This work was supported by the Amazonas State University (UEA, Universidade do Estado do Amazonas) and the graduate program of Biotechnology and Natural Resources (PPG-MBT).

\section{References}

1. Morley JE, Farr SA, Nguyen AD. Alzheimer Disease. Clin Geriatr Med. 2018 Nov;34(4):591-601. https://doi.org/10.1016/j.cger.2018.06.006

2. Fernández-Albarral JA, Salobrar-García E, Martínez-Páramo R. Retinal glial changes in Alzheimer's disease: a review.. J Optom. 2019 Jul-Sep;12(3):198-207.

3. Bettens K, Sleegers K, Van Broeckhoven C. Genetic insights in Alzheimer's disease. Lancet Neurol. 2013 Jan;12(1):92-104. https://doi.org/10.1016/S1474-4422(12)70259-4

4. Heywood WE, Hallqvist J, Heslegrave AJ, Zetterberg H, Fenoglio C, Scarpini E, et al. CSF pro-orexin and amyloid- $\beta 38$ expression in Alzheimer's disease and frontotemporal dementia. Neurobiol Aging. 2018 Dec;72:171-6. https://doi.org/10.1016/j.neurobiolaging.2018.08.019

5. Fridman C, Gregório SP, Dias Neto E, Ojopi ÉP. Alterações genéticas na doença de Alzheimer. Rev Psiquiatr Clin (Santiago). 2004;31(1):19-25. https://doi.org/10.1590/S0101-60832004000100004

6. Ward BE, Cook RH, Robinson A, Austin JH, Summitt RL. Increased aneuploidy in Alzheimer disease. Am J Med Genet. 1979;3(2):137-44. https://doi.org/10.1002/ajmg.1320030204

7. Buckton KE, Whalley LJ, Lee M, Christie JE. Chromosome changes in Alzheimer's presenile dementia.J Med Genet. 1983 Feb;20(1):46-51. https://doi.org/10.1136/jmg.20.1.46

8. White BJ, Crandall C, Goudsmit J, Morrow CH, Alling DW, Gajdusek DC, et al. Cytogenetic studies of familial and sporadic Alzheimer disease. Am J Med Genet. 1981;10(1):77-89. https://doi.org/10.1002/ajmg.1320100110

9. Yurov YB, Vorsanova SG, Liehr T, Kolotii AD, lourov IY.X chromosome aneuploidy in the Alzheimer's disease brain. Mol Cytogenet. 2014 Mar;7(1):20. https://doi.org/10.1186/1755-8166-7-20
10. Schellenberg GD, Bird TD, Wijsman EM, Orr HT, Anderson L, Nemens E, et al. Genetic linkage evidence for a familial Alzheimer's disease locus on chromosome 14. Science. 1992 Oct;258(5082):668-71. https://doi.org/10.1126/science.1411576

11. Levy-Lahad E, Wasco W, Poorkaj P, Romano DM, Oshima J, Pettingell WH, et al. Candidate gene for the chromosome 1 familial Alzheimer's disease locus. Science. 1995 Aug;269(5226):973-7. https://doi.org/10.1126/science.7638622

12. Rogaeva E. The solved and unsolved mysteries of the genetics of early-onset Alzheimer's disease. Neuromolecular Med. 2002;2(1):1-10. https://doi.org/10.1385/NMM:2:1:01

13. Folstein MF, Folstein SE, McHugh PR. "Mini-mental state". A practical method for grading the cognitive state of patients for the clinician. J Psychiatr Res. 1975 Nov;12(3):189-98. https://doi.org/10.1016/0022-3956(75)90026-6

14. Tombaugh TN, Mclntyre NJ. The mini-mental state examination: a comprehensive review. J Am Geriatr Soc. 1992 Sep;40(9):922-35. https://doi.org/10.1111/j.1532-5415.1992.tb01992.x

15. Moorhead PS, Nowell PC, Mellman WJ, Battips DM, Hungerford DA. Chromosome preparations of leukocytes cultured from human peripheral blood. Exp Cell Res. 1960 Sep;20(3):613-6. https://doi.org/10.1016/0014-4827(60)90138-5

16. Gold JR, Li YC, Shipley NS, Powers PK. Improved methods for working with fish chromosomes with a review of metaphase chromosome banding. J Fish Biol. 1990;37(4):563-75. https://doi.org/10.1111/j.1095-8649.1990.tb05889.x

17. Arendt T. Cell cycle activation and aneuploid neurons in Alzheimer's disease. Mol Neurobiol. 2012 Aug;46(1):125-35. https://doi.org/10.1007/s12035-012-8262-0 
18. Lourov IY, Vorsanova SG, Liehr T, Yurov YB. Aneuploidy in the normal, Alzheimer's disease and ataxia-telangiectasia brain: differential expression and pathological meaning. Neurobiol Dis. 2009 May;34(2):212-20. https://doi.org/10.1016/j.nbd.2009.01.003

19. Iourov IY, Vorsanova SG, Yurov YB. Genomic landscape of the Alzheimer's disease brain: chromosome instability - aneuploidy, but not tetraploidy - mediates neurodegeneration. Neurodegener Dis. 2011;8(1-2):35-7.

20. Iourov IY, Vorsanova SG, Yurov YB. Somatic cell genomics of brain disorders: a new opportunity to clarify genetic-environmental interactions. Cytogenet Genome Res. 2013;139(3):181-8. https://doi.org/10.1159/000347053

21. Spremo-Potparevic B, Bajic V, Perry G, Zivkovic L. Alterations of the X Chromosome in lymphocytes of Alzheimer's disease patients. Curr Alzheimer Res. 2015;12(10):990-6. https://doi.org/10.2174/1567205012666151027124154

22. Ried T. Homage to Theodor Boveri (1862-1915): boveri's theory of cancer as a disease of the chromosomes, and the landscape of genomic imbalances in human carcinomas. Environ Mol Mutagen. 2009 Oct;50(8):593-601. https://doi.org/10.1002/em.20526

23. Bender BG, Linden MG, Robinson A. Neuropsychological impairment in 42 adolescents with sex chromosome abnormalities. Am J Med Genet. 1993 Oct;48(3):169-73. https://doi.org/10.1002/ajmg.1320480312

24. Bajić VP, Spremo-Potparević B, Zivković L, Bonda DJ, Siedlak SL, Casadesus G, et al. The X-chromosome instability phenotype in Alzheimer's disease: a clinical sign of accelerating aging? Med Hypotheses. 2009 Dec;73(6):917-20. https://doi.org/10.1016/j.mehy.2009.06.046

25. Fantin C, Prazeres VG, Benzaquem DC, Fernandes ER, Oliveira DP, Ribeiro-Lima JC. Cytogenetic diagnosis and analysis of the clinical profile of individuals with non-down syndrome intellectual disability. J Pharm Pharmacol. 2017;5:812-20. https://doi.org/10.17265/2328-2150/2017.11.004

26. Bajic V, Mandusic V, Stefanova E, Bozovic A, Davidovic R, Zivkovic $\mathrm{L}$, et al. Skewed X-chromosome inactivation in women affected by Alzheimer's disease. J Alzheimers Dis. 2015;43(4):1251-9. https://doi.org/10.3233/JAD-141674
27. Spremo-Potparevic B, Zivkovic L, Djelic N, Bajic V. Analysis of premature centromere division (PCD) of the X chromosome in Alzheimer patients through the cell cycle. Exp Gerontol. 2004 May;39(5):849-54. https://doi.org/10.1016/j.exger.2004.01.012

28. Zivković L, Spremo-Potparević B, Plecas-Solarović B, Djelić N, Ocić G, Smiljković P, et al. Premature centromere division of metaphase chromosomes in peripheral blood lymphocytes of Alzheimer's disease patients: relation to gender and age. J Gerontol A Biol Sci Med Sci. 2010 Dec;65(12):1269-74. https://doi.org/10.1093/gerona/glq148

29. Spremo-Potparević B, Zivković L, Djelić N, PlećasSolarović B, Smith MA, Bajić V. Premature centromere division of the X chromosome in neurons in Alzheimer's disease. J Neurochem. 2008 Sep;106(5):2218-23. https://doi.org/10.1111/j.1471-4159.2008.05555.x

30. Micale M, Insko J, Ebrahim SA, Adeyinka A, Runke C, Van Dyke DL. Double trisomy revisited - a multicenter experience. Prenat Diagn. 2010 Feb;30(2):173-6. https://doi.org/10.1002/pd.2429

31. Subramaniyam S, Pulijaal VR, Mathew S. Double and multiple chromosomal aneuploidies in spontaneous abortions: A single institutional experience. J Hum Reprod Sci. 2014 Oct-Dec;7(4):262-8. https://doi.org/10.4103/0974-1208.147494

32. Ortiz GG, Pacheco-Moisés FP, González-Renovato ED, Figuera L, Macías-Islas MA, Mireles-Ramírez M. Genetic, biochemical and histopathological aspects of familiar Alzheimer's disease. Alzheimer's Dis. 296-324, 2015

33. Geller LN, Potter H. Chromosome missegregation and trisomy 21 mosaicism in Alzheimer's disease. Neurobiol Dis. 1999 Jun;6(3):167-79. https://doi.org/10.1006/nbdi.1999.0236

34. Hultén MA, Jonasson J, Nordgren A, Iwarsson E. Germinal and somatic trisomy 21 mosaicism: how common is it, what are the implications for individual carriers and how does it come about? Curr Genomics. 2010 Sep;11(6):409-19. https://doi.org/10.2174/138920210793176056

35. Potter H, Granic A, Caneus J. Role of Trisomy 21 Mosaicism in Sporadic and Familial Alzheimer's Disease. Curr Alzheimer Res. 2016;13(1):7-17. https://doi.org/10.2174/156720501301151207100616 